\title{
Practices of Counter Pressure and Birth Ball Exercise Combination to Increase $\beta$-Endorphin Hormone Levels in Labor Pain
}

\author{
$1^{\text {st }}$ Novita Sari \\ Department of Midwifery \\ STIKES Karya Husada Semarang \\ Semarang, Indonesia \\ novitasarifaase7@gmail.com \\ $4^{\text {th }}$ Tri Ismu Pujiyanto \\ Department of Midwifery \\ STIKES Karya Husada Semarang \\ Semarang, Indonesia
}

\author{
$2^{\text {nd }}$ Runjati \\ Department of Midwifery \\ Poltekkes Kemenkes Semarang \\ Semarang, Indonesia
}

\author{
$3^{\text {rd }}$ Diyah Fatmasari \\ Department of Midwifery \\ Poltekkes Kemenkes Semarang \\ Semarang, Indonesia
}

\begin{abstract}
Labor pain is a subjective experience regarding physical sensations that occur due to uterine contractions, dilation and thinning of the cervix and is a physiological sensation. The pain occurs due to the transmission of pain impulses through certain nerves. Inefficient uterine contractions could affect the mother's condition in the form of fatigue, fear, and stress. Nonpharmacological methods used to reduce labor pain is counterpressure and birth ball exercise combination which applying pressure using the base of the hand on the sacral bone and lumbar of the mother by sitting on the birth ball during a contraction so that can reduce the sensation of pain transmission impulses to the brain. This type of research used a Quasi Experiment with a random cluster design pretest and posttest control group was used to determine the effect of the combination intervention to increase $\beta$-endorphin levels. 40 samples were divided into 2 groups using purposive sampling technique. Each group consisted of 20 respondents. The result shows that the combination was more effective in increasing $\beta$-endorphin levels compared to back massage seen from the p-value 0.002 ( $p<0.05$ ) which means there is a difference in betaendorphin levels of the treatment group and the control group.
\end{abstract}

Keywords-Counter Pressure, Birth Ball, B-Endorphin Hormone, Labor Pain

\section{INTRODUCTION}

Labor pain is a subjective experience of physical sensations that transpire to uterine contractions, dilation and thinning of the cervix and is a physiological sensation that the patient feels during childbirth. [1,7] Improper management of labor pain could cause uncoordinated uterine activity which will result in prolonged labor. $[2,12]$ Labor pain that causes prolonged labor will have serious effects including intra-partum infection, uterine rupture, pathological retraction ring, fistula formation, pelvic muscle tissue injury, and use for head of succedaneum and molasses. $[3,15]$ Research related to the incidence of pain during labor, there are $65 \%$ caused by inefficient uterine contractions.[4,13] Counter pressure massage is a massage that applying pressure continuous using the base of the hand or fist of one hand on the sacral bone and lumbar region of the patient during a contraction so that it can help reduce the sensation of pain and transmission of pain impulses to the brain. Counter pressure can be applied in lying down position or halfsitting position, depends on the comfort of the mother position. $[5,10]$ There are many techniques for performing massage, including counter pressure techniques. There are differences in the way or place of massage so that it has different effects and sensations.[6,8] One of the relaxation techniques and other non-pharmacological actions in handling pain during childbirth is by using birth ball exercises which are also commonly known in Pilates exercises as fitball, Swiss ball and petzi ball. $[5,9,11]$ To prove the influence of both technique of counter pressure massage and birth ball exercise methods on labor pain, it is necessary to combine the two methods in order to obtain a stronger effect in stimulating the $\beta$-endorphin hormone and the relaxation effect will be more maximal so that the increase in intensity decreases labor pain will be optimal. $[8,10,14]$ Counter pressure can be applied in lying down position or half-sitting position, depends on the comfort of the mother position.

\section{METHOD}

\section{A. Framework}

This study was divided into 2 groups in the intervention group (a combination of Counterpressure and Birthball Exercise) and in the control group (back massage according to standard operating procedures), each group had 20 respondents, which were obtained by conducting an assessment of primigravida trimester III pregnant women who examined at the health center and have compatible the inclusion criteria.

Measurements were made by taking $3 \mathrm{cc}$ venous blood to test the analysis of the hormone $\beta$-Endorphin hormone before the intervention, then a combination intervention counterpressure and birth ball exercise 2 times in 30 minutes during treatment. Whereas the control group performed back massages 2 times in 30 minutes during treatment. 
Measurements were made by taking $3 \mathrm{cc}$ venous blood to test the analysis of the hormone $\beta$-Endorphin hormone before the intervention, then a combination intervention counterpressure and birth ball exercise 2 times in 30 minutes during treatment. Whereas the control group performed back massages 2 times in 30 minutes during treatment.

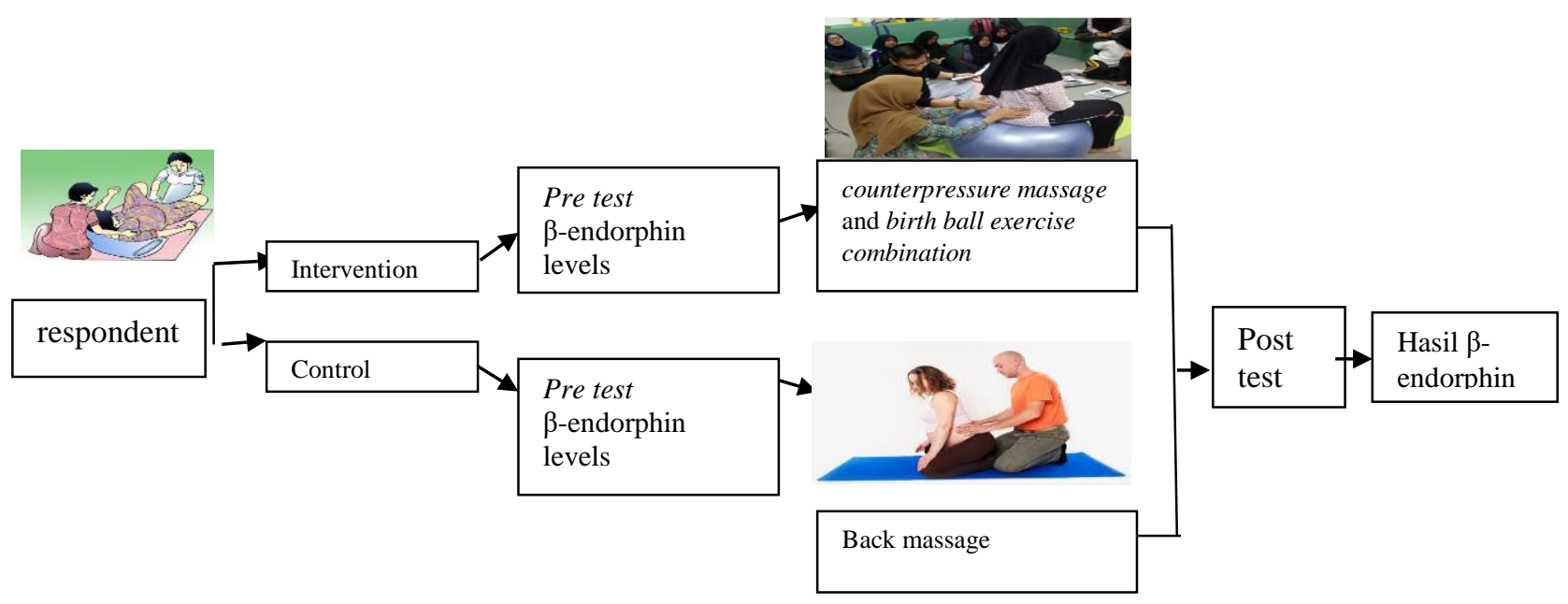

Figure 1. Framework

\section{B. Research Type and Design}

This type of research uses quasi-experimental with random cluster design pretest and posttest control group design. There were 40 samples divided into 2 groups with a purposive sampling technique. Each group consists of 20 respondents. Group 1 The treatment was given a combination of counterpressure and birth ball exercise interventions with measurements blood sampling for the inquiry of $\beta$-Endorphin hormone levels pre-test and posttest and group 2 performed back massage in accordance with measurements blood sampling for the inquiry of $\beta$ Endorphin hormone levels pre-test and post-test Analysis was used to assess differences in increase in betaendorphin levels used Independent Sample T-Test. Post measurements after complete overt, with the same questionnaire and taking post blood as much as $3 \mathrm{cc}$ intravenously. Analysis of $\beta$-endorphin hormone levels was carried out in the laboratory of the GAKI laboratory at the Faculty of Medicine, Diponegoro University, Semarang. Research ethics is informed consent, anonymity, confidentiality and truth. [20] Ethical approval was obtained from the Karya Husada Semarang Health Research Ethics Committee.

\section{RESULT AND DISCUSSION}

A. Characteristics of Respondent

Characteristics of respondents include the characteristics of age, education, occupation, and psychological condition of mothers in the treatment group and the control group can be seen through the following table:

TABLE 1. CHARACTERISTICS OF RESPONDENTS

\begin{tabular}{|c|c|c|c|c|c|c|c|}
\hline \multirow{3}{*}{ Characteristics } & \multicolumn{6}{|c|}{ Group } & \multirow{3}{*}{$p$ valuc } \\
\hline & \multicolumn{3}{|c|}{ Intervention } & \multicolumn{3}{|c|}{ Control } & \\
\hline & $\mathrm{N}$ & $(\%)$ & Mean \pm SD & $\mathrm{n}$ & $(\%)$ & Mean \pm SD & \\
\hline Age & & & $23,95 \pm 3,332$ & & & $22,65 \pm 3,951$ & 0,433 \\
\hline$<20$ years old & 6 & 30,0 & & 4 & 20,0 & & \\
\hline $\begin{array}{l}21-25 \text { years old } \\
>25 \text { years old }\end{array}$ & $\begin{array}{l}5 \\
9\end{array}$ & $\begin{array}{l}25,0 \\
45,0\end{array}$ & & $\begin{array}{l}6 \\
10\end{array}$ & $\begin{array}{l}30,0 \\
50,0\end{array}$ & & \\
\hline Education & & & $2,00 \pm 0,649$ & & & $2,20 \pm 0,616$ & 0,570 \\
\hline SD-SMP & 4 & 20,0 & & 2 & 10,0 & & \\
\hline SMA & 12 & 60,0 & & 12 & 60,0 & & \\
\hline Diploma-S1 & 4 & 20,0 & & 6 & 30,0 & & \\
\hline $\begin{array}{l}\text { Occupation } \\
\text { Work } \\
\text { Doesn't work }\end{array}$ & $\begin{array}{l}14 \\
6 \\
\end{array}$ & $\begin{array}{l}70,0 \\
30,0 \\
\end{array}$ & $1,30 \pm 0,470$ & $\begin{array}{l}8 \\
12 \\
\end{array}$ & $\begin{array}{l}40 \\
60 \\
\end{array}$ & $1,06 \pm 0,503$ & 0,216 \\
\hline Psychological & & & $1,10 \pm 0,308$ & & & $1,20 \pm 0,410$ & 0,080 \\
\hline Not worried & 0 & 0 & & 1 & 5,0 & & \\
\hline mild anxiety & 2 & 10,0 & & 4 & 20,0 & & \\
\hline moderate & 18 & 90,0 & & 16 & 80,0 & & \\
\hline very worried & 0 & 0 & & 0 & 0 & & \\
\hline${ }^{c}$ Levene's Test & & & & & & & \\
\hline
\end{tabular}

The age, education, occupation and psychological data between the treatment group and the control group have homogeneous or similar data variants ( $\mathrm{p}$ value> $0.05)$. 
Education is one of the factors that influences a person's level of knowledge, the higher the level of mother's education, the more her knowledge and awareness increases in anticipating the difficulties of pregnancy and childbirth so that it motivates to carry out regular and periodic pregnancy control. [16]

\section{B. Effectiveness of the counterpressure practice and} birth ball exercise combination to increase the level of $\beta$-Endorphin hormones group 1 treatment compared to the control group

$\beta$-endorphin hormone levels before and after the intervention group in the application of a combination of counterpressure and birth ball exercise 0.015 ( $\mathrm{p}<0.05)$ means that there are differences in the value of $\beta$ endorphin before and after the intervention in the treatment group. Whereas in the control group back massage $p$-value before and after back massage 0.155 (p> 0.05 ) means that there is no difference in the levels of the $\beta$-endorphin hormone before and after the intervention group.

The average difference in the level of $\beta$-endorphin hormone in the treatment group was $32.90 \mathrm{ng} / \mathrm{mL}$ while the control group was $-17.26 \mathrm{ng} / \mathrm{mL}$ it could be said that the application of a combination of counterpressure and birth ball exercise was more effective in increasing betaendorphin levels compared to the application of back massage seen from $p$-value $0.002(p<0.05)$ which means that there are differences in the levels of the $\beta$-endorphin hormone in the treatment group and the control group.

\section{CONCLUSION}

Based on the results of research and discussion on the application of a combination of counterpressure and birth ball exercise to the $\beta$-endorphin hormone levels in primigravida first-time mothers that have been described, it can be concluded that the combination of counterpressure and birth ball exercise is effective against increasing levels of the $\beta$-Endorphin hormone during labor in the active phase I compared to the control group. Confounding variables based on psychological, the majority of $90 \%$ of respondents experienced moderate anxiety where 18 respondents had an increase in betaendorphine levels above the average, while $10 \%$ of respondents had an increase in beta-endorphine levels below the average. It can be concluded that the two groups have homogeneous psychological score equivalents. Maternal psychological preparation greatly determines the success of the birth process, the psychological state of the mother who is depressed, sad, and tense will determine the intensity of pain during labor.[18,19]

The combination of counterpressure and birth ball exercise is one way to avoid complications caused by anxiety by using a method that can reduce the increase in the hormone adrenaline in the body of a giving birth mother who is the cause of anxiety. Pleasant sensory stimuli cause the release of beta-endorphine which can inhibit anxiety stimuli resulting in less anxiety stimuli transmitted to the brain. [20]
Confounding variables based on age, the majority of respondents in the treatment group and the control group were in the ideal range of reproduction, namely age 21-25 years, in the treatment group by $45 \%$ and control groups $50 \%$. The results of this study indicate that the two groups were not affected by age characteristics on labor pain intensity and $\beta$-endorphin hormone levels. [17]

\section{REFERENCES}

[1] Felaili SE. Teknik Kneading Menurunkan Tingkat Nyeri Persalinan Kala I Pada Ibu Bersalin Di Kabupaten Semarang. Jurnal Kebidanan. 2017;9(01).

[2] Levett KM. The complete birth study: effectiveness of a complex antenatal education program incorporating complementary medicine techniques for pain relief in labour and birth for firsttime mothers: a mixed methods study [The complementary therapies for labour and birth study: effectiveness of a complex antenatal education program incorporating complementary medicine techniques for pain relief in labour and birth for firsttime mothers: a mixed methods study]. 2015.

[3] Wiknjosastro H. Ilmu Kandungan. Jakarta: Yayasan Bina Pustaka Sarwono Prawirohardjo; 2010.

[4] Bikum L. Pengaruh Pijat Counter Pressure Terhadap Tingkat Nyeri Ibu Bersalin Kala I Fase Aktif Di Bpm Ellok Ekaria Safitri Gedongkiwo Yogyakarta. 2015.

[5] Akbarzadeh M, Masoudi Z, Hadianfard MJ, Kasraeian M, Zare N. Comparison of the effects of maternal supportive care and acupressure (BL32 acupoint) on pregnant women's pain intensity and delivery outcome. Journal of pregnancy. 2014;2014.

[6] Biswan M, Novita H, Masita M. Efek Metode Non Farmakologik terhadap Intensitas Nyeri Ibu Bersalin Kala I. Jurnal Kesehatan. 2017;8(2):282-8.

[7] Benedetto, Chiara, et al. 2017 Pain Control During Labour. In Neonatal Pain. Pp. 29-34: Springer.

[8] Damayanti, Ika Putri 2017 The Correlations Of Massage With A Childbirth Progress. Menara Ilmu 11(74).

[9] Fournier, Danielle, Gloria Feeney, and Marie-Eve Mathieu 2017 Outcomes of Exercise Training Following the Use of a Birthing Ball During Pregnancy and Delivery. The Journal of Strength \& Conditioning Research 31(7):1941-1947.

[10] Hosseini, Ebrahim, Nasrin Asadi, and Fatemeh Zareei 2013 Effect of massage therapy on labor progress and plasma levels of cortisol in the active stage of first labor. Zahedan Journal of Research in Medical Sciences 15(9):35-38.

[11] James, Sindiwe, and Melissa Hudek $2017 \quad$ Experiences of South African multiparous labouring women using the birthing ball to encourage vaginal births. Health SA Gesondheid 22:36-42.

[12] Jelting, Y, et al. 2017 Patient-controlled analgesia with remifentanil vs. alternative parenteral methods for pain management in labour: a Cochrane systematic review. Anaesthesia 72(8):1016-1028.

[13] Jones, Leanne, et al. 2012 Pain management for women in labour: an overview of systematic reviews. Cochrane database of systematic reviews (3).

[14] Lestari, Indah 2016 Pengaruh Deep Back Massage Terhadap Penurunan Nyeri Persalinan Kala I Fase Aktif dan Kecepatan Pembukaan Pada Ibu Bersalin Primigravida. Jurnal Keperawatan Bina Sehat 3(1)

[15] Medley, Nancy, et al. 2017 Interventions during pregnancy to prevent spontaneous preterm birth: an overview of Cochrane systematic reviews. The Cochrane Library.

[16] Adam J. Hubungan antara Umur, Parietas dan Pendampingan Suami dengan Intensitas Nyeri Persalinan Kala I Fase Aktif Deselarasi di Ruang Bersalin RSUD Prof. Dr. H. Aloei Saboe Kota Gorontalo. JIKMU. 2015;5(4).

[17] Jelting Y, Weibel S, Afshari A, Pace N, Jokinen J, Artmann T, et al. Patient-controlled analgesia with remifentanil vs. alternative parenteral methods for pain management in labour: a Cochrane systematic review. Anaesthesia. 2017;72(8):1016-28.

[18] Nurdiati, Detty S, et al. $2017 \quad$ Efektivitas Pijat Effleurage Dan Counterpressure Terhadap Penurunan Nyeri Persalinan Dan Kemajuan Dilatasi Serviks Pada Kala I Fase Aktif Di Bidan Praktik Mandiri Surabaya, Universitas Gadjah Mada. 
[19] Rejeki, Sri 2016

Counter-Pressure Practice Method by Spuses for Reducing Pain of Mothers In First Stage Labour. 2nd International Seminar on Education Technology 2016, 2016. State University of Semarang.

[20] Elkheshen S, Mohamed HS, Abdelgawad H. The Effect of Practicing Pelvic Rocking Exercise on Lowering Disability Level through Decreasing Pregnancy Related Lower Back Pain. 2016. 